\title{
Pharmaciana
}

Vol. 8, No.1, May 2018, Page. 145-154

ISSN: 2088 4559; e-ISSN: 24770256

DOI: $10.12928 /$ pharmaciana.v8i1.7511

\section{Total phenol, flavonoid, and anthocyanin content and antioxidant activity of Etlingera elatior extract nanoparticle}

\author{
Tresna Lestari*, Tita Nofianti, Lilis Tuslinah, Ruswanto, Yulia Salmini, Dewi Dewi, \\ Leli Siti Zaqiah, Anggi Agustira, Putri Pratiwi \\ Sekolah Tinggi Ilmu Kesehatan Bakti Tunas Husada \\ Jl. Cilolohan No 36 Tasikmalaya 46115
}

Submitted: 09-10-2017

Reviewed: 12-12-2017

Accepted: 03-03-2018

\begin{abstract}
Despite the long and wide application, traditional medicine is known for its minimum efficacy. Nanoparticle technology has reported to optimally address this weakness by enhancing the ability of the medicine to penetrate the biological membrane and, thereby, increasing the absorption. In this research, Etlingera elatior (ginger flower) extract, which has antioxiandt activity, was formulated into nanoparticles with ionotropic gelation method using chitosan $(0.08,0.09,0.1,0.2$, and $0.3 \%)$ and $0.01 \%$ NaTPP. The nanoparticles were characterized by their particle size, polydispersity index, zeta potential, and entrapment efficiency against total phenolic compound, flavonoid, and anthocyanin. The ones with the best properties were then analyzed with Scanning Electron Microscopic (SEM) method and tested for its antioxidant activity against DPPH. The results showed that all of the formula variations produced particle size in the range of 147.0-566.2 $\mathrm{nm}$ with a polydispersity index of $<0.5$ and zeta potential between $0.45-45.90 \mathrm{mV}$. Also, the absorption efficiencies of phenol, flavonoid, and anthocyanin were $72.62-84.24 \%, 55.18-92.05 \%$, and $75.67-97.96 \%$, respectively. Overall, the best characteristics were presented by the combination of $0.1 \%$ chitosan and $0.01 \%$ NaTPP, which produced 246.4-nm nanoparticles with a polydispersity index of 0.418 , and zeta potential of $26.60 \mathrm{mV}$. These nanoparticles also contained phenol, flavonoid, and anthocyanin with good absorption efficiencies, namely $78.5186 \%, 92.05 \%$, and $97.96 \%$, respectively. SEM analysis showed that these nanoparticles were round and had a soft surface. The radical scavenging activities of the extract and the nanoparticles against $\mathrm{DPPH}$, as presented by the $\mathrm{IC}_{50}$ values, were $19.614 \mathrm{ppm}$ and $160 \mathrm{ppm}$.
\end{abstract}

Keywords: ginger flower extract, nanoparticle, antioxidant

\footnotetext{
Corresponding author:

Tresna Lestari

Program Studi S1 Farmasi, Sekolah Tinggi Ilmu Kesehatan Bakti Tunas Husada

Jl. Cilolohan No 36 Tasikmalaya 46115 Jawa Barat

Email: tresnalestari@stike-bth.ac.id
} 


\section{INTRODUCTION}

The high antioxiandt capacity of plants is estimated to significantly contribute to the healing activity produced by herbal dosage forms. Various studies found that plant-based food ingredients have a much higher antioxiandt capacity than their animal-based counterparts. Among of the reasons are the active antioxiandt compounds like flavonoids and polyphenols, tannins, phenolic and lignin acids, vitamin $\mathrm{C}$, vitamin $\mathrm{E}$, beta-carotene, and pigments like anthocyanin and chlorophyll in plants (Carlsen et al., 2010; Tilak and Devasagayam, 2006).

Herbal dosage forms are often considered less effective due to their weak and slow activity. To overcome this problem, the application of formulation technology for herbal dosage forms is necessary; one of which is the use of nano-sized extract. Nanoparticle dosage form can increase the absorption of medicine and, therefore, improve its bioavailability in the blood. Particle size reduction into nanoscale widens the surface area of contact and enhances the efficiency of particle internalization into the lipid bilayer (Won et al., 2008).

Etlingera elatior, or known as ginger flower, is one of many plants that have the potential to be developed as an herbal dosage form. The previous study has successfully optimized the extraction of polyphenol compounds from E. elatior. Polyphenol compounds have better solubility in polar rather than semi-polar solvents but exhibit no reaction in non-polar ones (Lestari and Ruswanto, 2015). In a different study, they are found to have higher solubility in methanol solvent $(1.114 \mathrm{~g} \mathrm{GAE} / 100 \mathrm{~g}$ extract) compared to ethanol ( $0.788 \mathrm{~g} \mathrm{GAE} / 100 \mathrm{~g}$ extract) and acetic acid ( $0.812 \mathrm{~g} \mathrm{GAE} / 100 \mathrm{~g}$ extract) (Munawaroh et al., 2014). This finding is line with another study, which proves that the methanol extract of E. elatior exhibits the highest antioxiandt activity $\left(\mathrm{IC}_{50}=19.919 \mu \mathrm{g} / \mathrm{mL}\right)$ than ethanol extract $\left({ }_{\mathrm{IC} 50}=36.810 \mu \mathrm{g} / \mathrm{mL}\right)$ and acetic acid $\left(\mathrm{IC}_{50}=23.233 \mu \mathrm{g} / \mathrm{mL}\right)($ Lestari et al., 2015). E. elatior contains components that, in fact, have a great capability to scavenge free radicals to prevent oxidation (Adliani, 2012).

This research aimed to provide herbal-based medicinal active ingredients, particularly of $E$. elatior, in nano size for the manufacture of herbal dosage forms. The use of nanoparticle was to increase the therapeutic effectiveness of this dosage form.

\section{MATERIALS AND METHODS \\ Tools and Materials}

The tools used in this research were reflux apparatus, rotary evaporator (IKA), UV-Vis spectrophotometer (Genesis 10), magnetic stirrer (IKA RW 20 Digital with heater), Beckman Coulter Delsa ${ }^{\mathrm{TM}}$ Nano particle analyzer, and Scanning Electron Microscope (SEM). The research materials included ginger flower, $\mathrm{n}$-hexane $\mathrm{p}$ (Bratachem), methanol $\mathrm{p}$ (Bratachem), methanol pa (Bratachem), thin layer chromatography plates (Merck), 1,1-diphenyl-2-picrylhydrazyl/DPPH (Sigma), glacial acetic acid (Merck), aqua deion, chitosan (Chimultiguna), sodium tripolyphosphate (Sigma), gallic acid (Sigma), Folin-Denis reagent (Sigma), and quercetin (Sigma).

\section{Procedure of Experiment}

Sample collection and test on the standard parameter of simplicia

The samples of the ginger flower were obtained from areas in Tasikmalaya and tested for quality according to the standards issued in Farmakope Herbal Indonesia 2011.

\section{Extraction}

The simplicia was extracted with multi-stage reflux. The first extraction used n-hexane solvent. After the color of this solvent disappeared, the simplicia was re-extracted with methanol until all compounds in the samples were extracted entirely. The resultant extracts were then concentrated, and their total phenol, total flavonoid, total anthocyanin, and antioxiandt activity were examined. 


\section{Nanoparticle production}

One gram of E. elatior extract was dissolved in $35 \mathrm{~mL}$ of methanol p.a and mixed with $15 \mathrm{~mL}$ of distilled water. It was added with $350 \mathrm{~mL}$ of $0.01 \%$ NaTPP gradually while stirred using a magnetic stirrer at $350 \mathrm{rpm}$ for 2 hours. The characterization of the nanoparticle suspensions was based on particle size, zeta potential, and absorption efficiency. Nanoparticles with the best characteristics were freeze-dried and tested for antioxiandt activity. Furthermore, their morphological nature was identified with SEM (Scanning Electron Microscope) (Firmawan, 2012).

\section{Identification of total phenolic content}

A sample of $0.5 \mathrm{~g}$ was weighed and dissolved in distilled water (the distilled water was added until $10 \mathrm{~mL}$ ). A sample of $1.0 \mathrm{~mL}$ of this solution was transferred with a pipet and added with $7.5 \mathrm{~mL}$ of distilled water. Then, it was added with $0.5 \mathrm{~mL}$ of Folin-Denis reactant, left for 3 minutes, and combined with $1.0 \mathrm{~mL}$ of saturated $\mathrm{Na}_{2} \mathrm{CO}_{3}$ solution. After 15 minutes, the absorption was read at the maximum wavelength. The total phenolic content was calculated as gallic acid using the linear regression equation $\mathrm{y}=\mathrm{a}+\mathrm{bx}$ (Mukhriani et al., 2014).

\section{Identification of total flavonoid content}

A sample of $50 \mathrm{mg}$ was dissolved in methanol p.a. in a $50 \mathrm{~mL}$ volumetric flask (methanol p.a. was added until the fill line). A sample of $1.0 \mathrm{~mL}$ of this solution was transferred with a pipet, mixed with $3 \mathrm{~mL}$ of methanol, $0.2 \mathrm{~mL}$ of $10 \%$ aluminum chloride solution, and $0.2 \mathrm{~mL}$ of $1 \mathrm{M}$ sodium acetate solution, and then added with distilled water until $10 \mathrm{~mL}$. It was incubated at room temperature for 30 minutes. Afterward, its absorption was measured at maximum $\lambda$. The total flavonoid content was calculated as quercetin using the linear regression equation $y=a+b x$ based on the test results (Ahmad et al., 2015).

\section{Identification of total anthocyanin content}

The total anthocyanin content was identified using $\mathrm{pH}$ differential method. The dilution factor was formed by diluting the sample with $\mathrm{KCl}-\mathrm{HCl}$ buffer $(\mathrm{pH}$ 1.0), to obtain an absorbance smaller than 1.2 times of the maximum wavelength of the extract. To measure the total anthocyanin content, two sample solutions were prepared. For the first sample, the extract was dissolved in $\mathrm{KCl}-\mathrm{HCl}$ buffer ( $\mathrm{pH}$ 1), while for the second sample, the extract was dissolved in sodium acetate buffer ( $\mathrm{pH} 4.5$ ). Each sample was dissolved in a buffer solution based on the predetermined dilution factor. Both sample solutions were incubated at room temperature for 15 minutes. The absorbance of each solution was measured at wavelengths of $510 \mathrm{~nm}$ and $700 \mathrm{~nm}$ (Giusti and Worlstad, 2001).

The final absorbance was calculated using the following equation.

$$
A=\left(A_{510}-A_{700}\right) p H 1-\left(A_{510}-A_{700}\right) p H 4.5
$$

The Total Anthocyanin Content (TAC) was calculated using the following equation.

$$
T A C(m g / L)=\frac{A \times M W \times D F \times 1,000}{\varepsilon \times I}
$$

where:

$$
\begin{aligned}
\mathrm{A} & =\text { final absorbance; } \\
\varepsilon & =\text { molar absorptivity of cyanidin-3-glucoside }=26900 \mathrm{~L} /(\mathrm{mol} . \mathrm{cm})
\end{aligned}
$$




\section{Measurement of absorption efficiency}

A sample of $5 \mathrm{~mL}$ of the nanoparticle suspension of E. elatior extract was added with $5 \mathrm{~mL}$ of borate alkaline ( $\mathrm{pH}$ 9.7). This mixture was centrifuged at 3,500 rpm for 30 minutes. The supernatant was sampled by $1 \mathrm{~mL}$, added with the appropriate reagent, and treated similarly for each compound analysis. The absorbance of the solution was measured at the proper wavelength, according to each compound. The results were then calculated as a free compound level (Iswananda, 2013).

$$
\text { Absorption ef ficiency }(\%)=\frac{\text { Level of compound in the extract-Level of free compound }}{\text { Level of compound in the extract }} \times 100 \%
$$

\section{Measurement of antioxiandt activity}

A sample of $50 \mathrm{mg}$ was weighed and dissolved in $100 \mathrm{~mL}$ of methanol p.a. with a concentration of $500 \mathrm{ppm}$. Six series of concentrations were created from the primary standard solution. Each of them was sampled by $1 \mathrm{~mL}$ with a pipet and added with $1 \mathrm{~mL}$ of $50 \mathrm{ppm}$ DPPH. These mixtures were left for 30 minutes. Their absorbance was measured at the maximum wavelength of DPPH solution (Lestari et al., 2015). The antioxiandt activity of the sample was determined by calculating the \%inhibition of DPPH absorbance using the following formula.

$$
\text { \%Inhibition }=\frac{D P P H \text { absorbance }- \text { Sample absorbance }}{D P P H \text { absorbance }} \times 100 \%
$$

where:

DPPH Absorbance $\quad=$ The absorbance of $0.2 \mathrm{M} \mathrm{DPPH}$ solution

Sample Absorbance $=$ The absorbance of the sample solution or comparative solution

Afterward, $\mathrm{IC}_{50}$ was calculated based on the concentration and the percentage inhibition using the linear regression equation $y=a+b x$.

\section{RESULTS AND DISCUSSION}

\section{The characteristics of the standard parameter of the simplicia}

The purpose of sample characterization is to obtain simplicia or herbal medicinal ingredients that meet the standards issued in applicable regulations. The test results showed that the samples meet the conditions described in Farmakope Herbal Indonesia 2011 (Table I).

\begin{tabular}{|c|c|c|c|c|c|}
\hline \multirow[b]{2}{*}{ Parameters } & \multicolumn{3}{|c|}{ Replication (\%) } & \multirow[b]{2}{*}{ Mean (\%) } & \multirow{2}{*}{$\begin{array}{c}\text { The Standards in } \\
\text { Farmakope Herbal } \\
2011(\%)\end{array}$} \\
\hline & I & II & III & & \\
\hline Water content & 5.00 & 5.00 & 5.00 & $5.00 \pm 0.0000$ & $\leq 10$ \\
\hline Total ash content & 8.98 & 8.97 & 8.96 & $8.97 \pm 0.0100$ & $\leq 10.6$ \\
\hline Acid-insoluble ash content & 1.54 & 1.38 & 1.29 & $1.40 \pm 0.1365$ & $\leq 4.7$ \\
\hline Loss on drying & 7.72 & 7.75 & 7.78 & $7.75 \pm 0.0076$ & $\leq 10$ \\
\hline $\begin{array}{l}\text { Water-soluble extract } \\
\text { content }\end{array}$ & 22.20 & 22.60 & 22.50 & $22.43 \pm 0.1266$ & $\geq 11.6$ \\
\hline $\begin{array}{c}\text { Ethanol-soluble extract } \\
\text { content }\end{array}$ & 22.98 & 23.20 & 22.95 & $23.04 \pm 0.0300$ & $\geq 16.5$ \\
\hline
\end{tabular}

Table I. The characteristics of the standard parameter of the simplicia

In addition to sample characterization, macroscopic and microscopic observations were performed to identify the unique morphology and physiology of the simplicia. Regarding the morphology, ginger 
flower has a shape like a spinning top inside a bouquet, a long peduncle $(0.5-2.5 \mathrm{~m} \mathrm{x} 1.5-2.5 \mathrm{~cm})$, oval bracts, and crimson-pink to bright red color. The corolla and calyx are pink, ovoid-shaped, and $4 \mathrm{~cm}$ long with white or yellow edges. Ginger flower has a distinctive odor and slightly sour flavor.

During the microscopic observation, the fragments of the ginger flower, as seen in Figure 1, were identified.

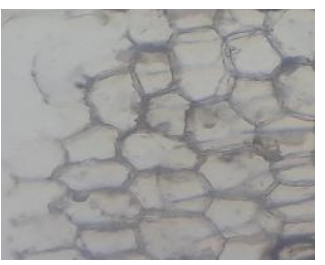

(a)

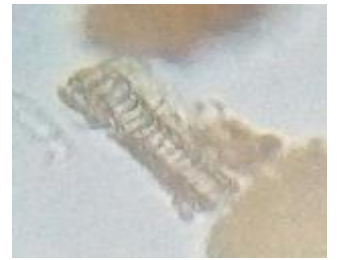

(d)

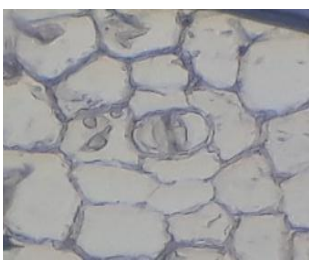

(b)

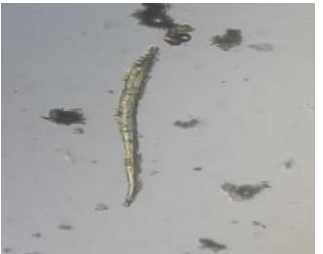

(e)

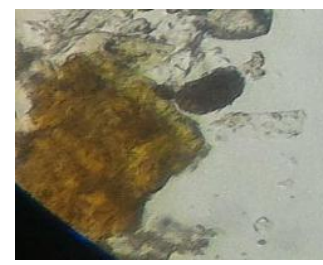

(c)

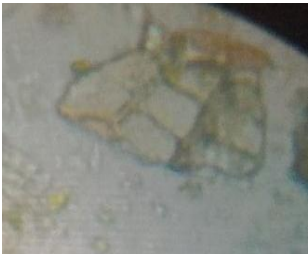

(f)

Figure 1. The results of microscopic observation: (a) Upper epidermis, (b) Stomata, (c) Oil glands, (d) Vascular tissue (transport), (e) Fragment of indumentum, (f) Epidermis of perianthium

The total phenol, flavonoid, and anthocyanin contents of the extract

There is a linear relationship between the antioxiandt activity and the phenolic content in $E$. elatior extract (Lestari et al., 2015; Munawaroh et al., 2014). Phenol, flavonoid, and anthocyanin are empirically proven to exhibit antioxiandt effects due to their ability to reduce free radicals. A higher phenolic content increases the antioxiandt activity produced by an extract (Ukieyanna, 2012).

The calculation results of the total phenol, flavonoid, and anthocyanin contents in the methanol extract of E. elatior are summarized in Table II.

Table II. The total phenol, flavonoid, and anthocyanin contents of Etlingera elatior extract

\begin{tabular}{ccccc}
\hline \multirow{2}{*}{ Compounds } & \multicolumn{3}{c}{ Replications } & \multirow{2}{*}{ Mean } \\
\cline { 2 - 4 } & I & II & III & \\
\hline Phenol & $7.26 \%$ & $7.23 \%$ & $7.29 \%$ & $7.26 \pm 0.0300 \%$ \\
Flavonoid & $8.20 \%$ & $8.23 \%$ & $8.27 \%$ & $8.23 \pm 0.0351 \%$ \\
Anthocyanin & $65.30 \mathrm{mg} / \mathrm{L}$ & $65.27 \mathrm{mg} / \mathrm{L}$ & $65.29 \mathrm{mg} / \mathrm{L}$ & $65.29 \pm 0.0153 \mathrm{mg} / \mathrm{L}$ \\
\hline
\end{tabular}

\section{The production and characterization of Etlingera elatior nanoparticle}

The nanoparticles were prepared with ionotropic gelation method using chitosan and NaTPP. This method relies on the ability of polyelectrolytes to produce a crosslink with negatively charged ions and to finally create a hydrogel. The binding of these anions with the cations of the polyelectrolyte solution forms a network that induces gelation. Hydrogels, a three-dimensional network, are formed by dripping NaTPP (anion solution) into the chitosan-based polyelectrolyte solution and the extract (Patil et al., 2010). 
Chitosan was made in different concentrations, i.e., $0.08,0.09,0.1,0.2$, and $0.3 \%$, while the concentration of NaTPP used in this research was $0.01 \%$. In this method, the chitosan and NaTPP solutions form ionic crosslinks to trap the extract as an active ingredient (Mohanraj \& Chen, 2006). Chitosan is a positively charged amino group, whereas NaTPP is negatively charged; all of which enable the occurrence of crosslinking (Chattopadhyay and Inamdar, 2010). The resultant nanoparticle suspensions were characterized by particle size, zeta potential, polydispersity index, and absorption efficiency (Table III).

Table III. The characteristics of the nanoparticle of Etlingera elatior extract

\begin{tabular}{|c|c|c|c|c|c|c|c|}
\hline \multirow{2}{*}{$\begin{array}{c}\text { Chitosan } \\
(\%)\end{array}$} & \multirow{2}{*}{$\begin{array}{c}\text { NaTPP } \\
(\%)\end{array}$} & \multirow{2}{*}{$\begin{array}{c}\text { Particle } \\
\text { Size } \\
(\mathbf{n m})\end{array}$} & \multirow{2}{*}{$\begin{array}{c}\text { Zeta } \\
\text { Potential } \\
(\mathbf{m V})\end{array}$} & \multirow{2}{*}{$\begin{array}{l}\text { Polydispersity } \\
\text { Index } \\
\text { (pdI) }\end{array}$} & \multicolumn{3}{|c|}{$\begin{array}{c}\text { Absorption Efficiency } \\
(\%)\end{array}$} \\
\hline & & & & & Phenol & Flavonoid & Anthocyanin \\
\hline 0.08 & 0.01 & 147.3 & 3.08 & 0.459 & 79.89 & 64.72 & 75.67 \\
\hline 0.09 & 0.01 & 231.8 & 15.70 & 0.391 & 84.24 & 55.18 & 80.33 \\
\hline 0.10 & 0.01 & 246.4 & 26.60 & 0.418 & 78.52 & 92.05 & 97.96 \\
\hline 0.20 & 0.01 & 483.4 & 45.90 & 0.491 & 75.46 & 83.39 & 93.85 \\
\hline 0.30 & 0.01 & 566.2 & 0.457 & 0.470 & 72.62 & 80.58 & 92.83 \\
\hline
\end{tabular}

The polymer absorptions of phenol, flavonoid, and anthocyanin were reasonably good with efficiency levels of $72.62-84.24 \%, 55.18-92.05 \%$, and $75.67-97.96 \%$, respectively. The characterization results showed that all formulations produced particles in the range of nanoscale

$(<1,000 \mathrm{~nm})$ and with a low polydispersity index $(<0.5)$. Low polydispersity index represents a stable dispersion system for a long period (Gao et al., 2008).

As a system containing dispersed particles, the stability of nanoparticles is represented by zeta potential. It refers to the degree of the repulsive force generated by adjacent, similarly charged particles in the dispersion. If the zeta potential is greater than $+30 \mathrm{mV}$ or less than $-30 \mathrm{mV}$, the system is deemed electrostatically stable. However, if it is greater than $+20 \mathrm{mV}$ or less than $-20 \mathrm{mV}$, the system is sterically stable (Gao et al., 2008).

Based on the results of zeta potential analysis, the best stability was produced by formulas composed of $0.2 \%$ chitosan $(45.9 \mathrm{mV})$. However, in general, nanoparticles with $0.1 \%$ chitosan had better characteristics because they produced smaller particle size $(246.4 \mathrm{~nm})$ and better absorption efficiency of the three compounds (phenol $=78.5186 \%$, flavonoid $=92.05 \%$, and anthocyanin $=$ $97.96 \%)$. These nanoparticles also had a fairly good polydispersity index, i.e., $0.418(<0.5)$, with a zeta potential of $26.60 \mathrm{mV}$. These parameters were the underlying reasons for the use of nanoparticles with $0.1 \%$ chitosan in further analysis. The SEM analysis results showed that these nanoparticles had round but nonuniform morphology with a smooth surface.

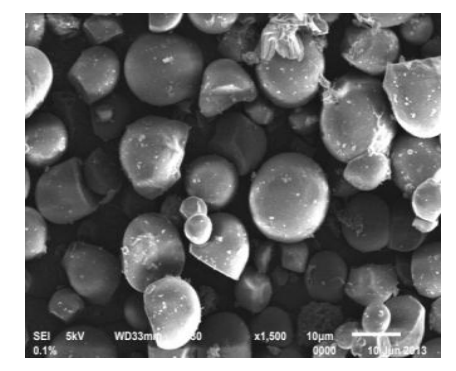

Figure 2. SEM analysis results of nanoparticles with $0.1 \%$ chitosan 


\section{The antioxidant activity of $E$. elatior extract and nanoparticles}

The antioxiandt activity was examined with thin layer chromatography (TLC) and UV-Vis spectrophotometry. When the extract was sprayed with DPPH reactant, the color of the spots changed to yellow with a purple plate on the background, indicating antioxiandt activity. DPPH reacted by scavenging one hydrogen atom from the antioxiandt compounds to form an electron pair, turning the DPPH free radicals into a stable DPPH-H (Windono et al., 2004).

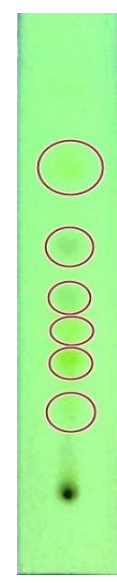

(a)

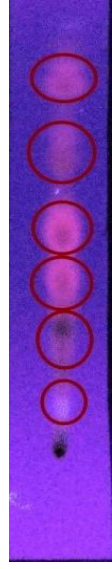

(b)

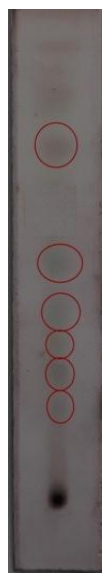

(c)

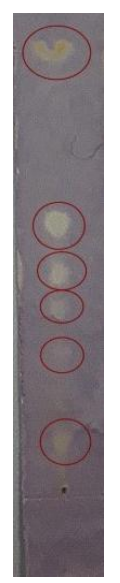

(d)

Figure 3. The thin layer chromatography of Etlingera elatior extract with the stationary phase "silica gel GF 254" and the mobile phase "ethyl acetate:n-hexane (7:3)": (a) observed under $U V_{254}$ light, (b) seen under $U V_{366}$ light, (c) sprayed with $\mathrm{H}_{2} \mathrm{SO}_{4}$ (visualization reagent) (d) sprayed with $1 \%$ DPPH

Afterward, the E. elatior extract and nanoparticle with $0.1 \%$ chitosan were tested for their antioxiandt activities with UV-Vis spectrophotometry. The test results showed that the antioxiandt activity of the extract decreased after the size was reduced to nanoparticles. Such decrease occurred because the amount of the extract in the nanoparticle production was considerably small $(0.2 \%)$.

In this research, antioxiandt activity was defined as the capacity of a sample to inhibit $50 \%$ $\mathrm{DPPH}$ as free radicals $\left(\mathrm{IC}_{50}\right)$. The analysis showed that the $\mathrm{IC}_{50}$ of the extract was $19.614 \mathrm{ppm}$, while the $\mathrm{IC}_{50}$ of the nanoparticles was $160 \mathrm{ppm}$. Compared to the findings of other studies, these figures show better activity. For instance, the methanol extract of Etlingera elatior obtained with maceration method was empirically found to exhibit an antioxiandt activity of $101.84 \mathrm{ppm}$. In a different research, the dosage form produced by the nanoencapsulation of E. elatior contained a total phenol of 289.86 $\mathrm{mg} / 100 \mathrm{~g}$, and its antioxiandt activity was $32.165 \%$ (Naufalin et al., 2011). Another antioxiandt activity analysis was performed on the liquid E. elatior extract, which was able to inhibit free radical with $\mathrm{IC}_{50}$ of 61.6497 ppm (Hudaya, 2010).

The different results of the studies above are caused by different extraction methods and sampling locations. In this research, the samples were obtained from Taraju District, Tasikmalaya Regency, West Java, while the methanol extract was obtained from multi-stage reflux with n-hexane and methanol solvent. This method is preferable because Etlingera elatior contains high fat and oil that can interfere with the extraction of active antioxiandt compounds, which are polar in nature, namely phenol, flavonoid, and anthocyanin. Using n-hexane solvent, non-polar compounds like fat and oil can be removed first so that the polar and active antioxiandt compounds can be extracted optimally with methanol solvent. This process was assumed to increase the antioxiandt activity of the resultant nanoparticles. 


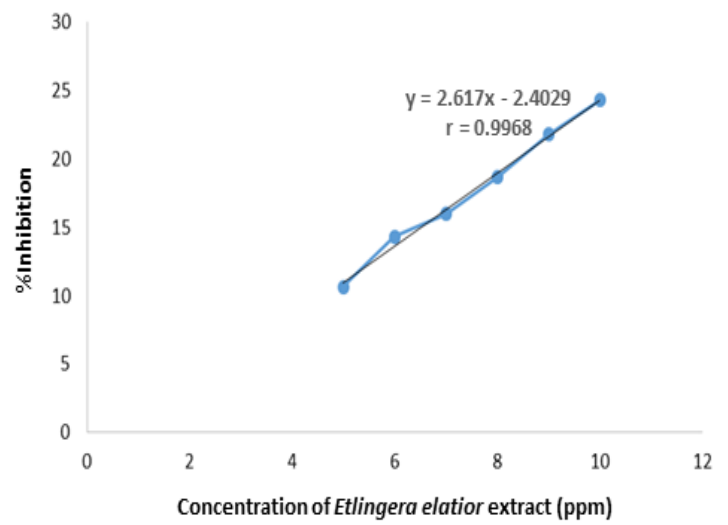

(a)

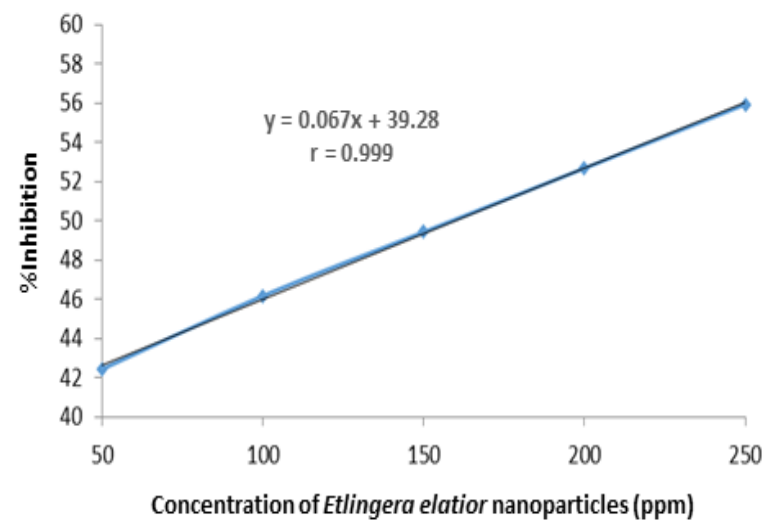

(b)

Figure 4. The regression curve of the antioxiandt activities of (a) Etlingera elatior extract and (b) nanoparticles

\section{CONCLUSION}

The simplicia used in this research has met some of the standards specified in Farmakobe Herbal Indonesia 2011. The total phenol, flavonoid, and anthocyanin contents of the methanol extract of E. elatior were $7.26 \pm 0.0300 \%, 8.23 \pm 0.0351 \%$, and $65.29 \pm 0.0153 \mathrm{mg} / \mathrm{L}$, respectively. Overall, the nanoparticles of the methanol extract of E. elatior, composed of chitosan and NaTPP, had a particle size in the range of $147.0-566.2 \mathrm{~nm}$ with a polydispersity index of $<0.5$. Their zeta potential varied between $0.45 \mathrm{mV}$ and $45.90 \mathrm{mV}$, while the absorption efficiencies of the phenol, flavonoid, and anthocyanin contents were $72.62-84.24 \%, 55.18-92.05 \%$, and $75.67-97.96 \%$, respectively. The best characteristics were presented by the combination of $0.1 \%$ chitosan and $0.01 \%$ NaTPP. This combination produced $246.4-\mathrm{nm}$ nanoparticles with a polydispersity index of 0.418 , zeta potential of $26.60 \mathrm{mV}$, and absorption efficiencies of $78.5186 \%$ (phenol), 92.05\% (flavonoid), and $97.96 \%$ (anthocyanin). The antioxiandt activity of the nanoparticles $\left(\mathrm{IC}_{50}=160 \mathrm{ppm}\right)$ was lower than the extract $\left(\mathrm{IC}_{50}=19.614 \mathrm{ppm}\right)$.

\section{ACKNOWLEDGMENT}

This research is supported by the Directorate of Research and Community Service, the Indonesian Ministry of Research, Technology, and Higher Education under the scheme of Applied Product Research Grant 2017.

\section{REFERENCES}

Adliani N., Nazliniwaty, dan Djendakita, 2012, Formulasi Lipstik Zat Warna Dari Ekstrak Bunga Kecombrang (Etlingera elatior (Jack) R. M. Sm), Journal of Pharmaceutics and Pharmacology, 1(2), 87-94.

Ahmad A.R., Juwita, Ratulangi S.A.D., dan Malik A., 2015, Penetapan Kadar Fenolik and Flavonoid Total Ekstrak Metanol Buah dan Daun Patikala (Etlingera elatior (jack) R.M.SM), Pharm Sci Ress, 2(1), 1-10.

Carlsen M.H, Bente L.H, Kari H., Siv K.B, Steinar D, Laura S, Carol W, Haruki S, Yuko U, Chiho S, Ingrid B, Nega B, Walter C.W, Katherine M.P, David R.J.Jr, Rune B, 2010, The total antioxiandt content of more than 3100 foods, beverages, spices, herbs and supplements used worldwide, Nutrition Journal, 9(3), 1-11. 
Chattopadhyay D.P., and Inamdar M.S., 2010, Aquoeus behavior of chitosan. International Journal of Polymer Science, 1-7.

Firmawan F., 2012, Pembuatan dan Karakterisasi Sediaan Nanopartikel Salbutamol Sulfat, Master Thesis, Program Studi Sains dan Teknologi Farmasi, Institut Teknologi Bandung.

Gao, L., Zhang D., and Chen. M, 2008, Drug nanocrystals for formulation of poorly soluble drugs and its application as potential drug delivery system, J. Nanopart Res, 10(1), 845-862.

Giusti M.M., and Worlstad R.E., 2001, Characterization and Measurement of Anthocyanins by UVVisible Spectroscopy, Oregon State University.

Hudaya A., 2010, Uji antioksiand dan antibakteri ekstrak air bunga kecombrang (Etlingera elatior) sebagai pangan fugsional terhadap Staphylococcus aureus dan Escherichia coli. Skripsi. Program Studi Biologi Fakultas Sains dan Teknologi. Bachelor Thesis. Universitas Syarif Hidayatulloh. Jakarta.

Iswananda, Anwar, and Jufri, 2013, Formulasi Nanopartikel Verapamil Hidroklorida dari Kitosan dan Natrium Tripolifosfat dengan Metode Gelasi Ionik, Jurnal Farmasi Indonesia, 6(4), 201-210.

Kementerian Kesehatan RI, 2011, Suplemen II Farmakope Herbal Indonesia, Edisi I. Jakarta: Kementrian Kesehatan Republik Indonesia.

Lestari T., and Ruswanto, 2015, Fitokimia Total Phenolic Content dan Sitotoksik Ekstrak and Minyak Atsiri Bunga Kecombrang (Etlingera elatior). Seminar Nasional and Diseminasi Penelitian Kesehatan, STIKes Bakti Tunas Husada, Tasikmalaya, 422-429.

Lestari T., Ira R., Lilis T., Siti M., and Anisa L., 2015, Total Phenolic Content and Antioxiandt Activity of Etlingera elatior Extract Under Different Solvent. Universitas Muhammadiyah Purwokerto-Pharmacy International Conference, Purwokerto, 1-8

Mohanraj V.J., and Chen Y., 2006, Nanoparticles - A Review, Trop J Pharl Res, 5(1), 561-573.

Mukhriani, Faridha Y.N., and Mumang, 2014, Penetapan Kadar Tanin Total Ekstrak Biji Jintan Hitam (Nigella sativa) Secara Spektrofotometri UV-VIS, Bachelor Thesis, Jurusan Farmasi Fakultas Ilmu Kesehatan Universitas Islam Negeri Alauddin Makassar.

Munawaroh S., Tresna L., and Ira R., 2014, Pengaruh Metode dan Variasi Pelarut Ekstraksi Terhadap Kadar Polifenolat Bunga Kecombrang (Etlingera elatior (Jack) R.M.Sm), Jurnal Kesehatan Bakti Tunas Husada, 12(1), 88-95.

Naufalin R., Tobari, and Herastuti, 2011, Nanoenkapsulan antioksiand alami berbahan dasar buah kecombrang (Nicolaia speciosa), Conference Paper, Fakultas Pertanian Universitas Jenderal Soedirman. 1-9.

Patil J.S., Kamalapur M.V., Marapur S.C., and Kadam D.V., 2010, Ionotropic Gelation and Polyelectrolyte Complexation: The Novel Thechniques to Design Hydrogel Particulate Sustained, Modulated Drug Delivery System: A Review, Digest Journal of Nanomaterial and Biostructures, 5(1), 241-248.

Tilak J.C. and Devasagayam T.P.A., 2006, Oxidative Damage to Mitochondria. In Singh, K. K., editor. Oxidative Stress, Disease and Cancer, Singapura: Mainland Press, 85-150.

Ukieyanna, E. 2012. Aktivitas antioksidan, Kadar Fenolik dan Flavonoid Total Tumbuhan Suruhan (Peperomia pellucida L. Kunth.), Bachelor Thesis, Departemen Biokimia, Fakultas Matematika and Ilmu Pengetahuan Alam, Institut Pertanian Bogor

Windono T., Riyanto B., Ivone S.V., and Yovita S., 2004, Studi Hubungan Struktur-Aktivitas Kapasitas Peredaman Radikal Bebas Senyawa Flavonoid Terhadap 1,1-difenil-2-pikrilhidrazil (DPPH), Artocarpus, 4(2), 48.

Won J., Oh M.-H., Kang M.-S., Choy J.-H., and Oh S., 2008, Stability Analysis of Zinc OxideNanoencapsulated Conjugated Linoleic Acid and Gamma-Linolenic Acid, Journal of Food Science, 73(8), 39-43. 
